\title{
The role of institutional and stakeholder networks in shaping social enterprise ecosystems in Europe
}

\author{
Richard Hazenberg${ }^{1}$, Meanu Bajwa-Patel ${ }^{1}$, Micaela Mazzei², Michael J. Roy², \\ and Simone Baglioni ${ }^{2}$ \\ ${ }^{1}$ Institute for Social Innovation and Impact, University of Northampton \\ ${ }^{2}$ Yunus Centre for Social Business and Health, Glasgow Caledonian University \\ Contact: Richard Hazenberg \\ richard.hazenberg@northampton.ac.uk
}

Cite as:

Hazenberg, R., Bajwa-Patel, M., Mazzei, M., Roy, M.J. and Baglioni, S. (2016) The Role of Institutional and Stakeholder Networks in Shaping Social Enterprise Ecosystems in Europe. Social Enterprise Journal 12 (3)

Authors' Pre-Publication Version 


\begin{abstract}
Purpose - This paper draws upon prior research that built a theoretical framework for the emergence of social enterprise ecosystems based upon biological evolutionary theory. This paper seeks to extend this previous research by practically applying the theory to the development of stakeholder and institutional networks across Europe.
\end{abstract}

Design/methodology/approach - Data from in-depth semi-structured interviews and focus groups were analysed using Constant Comparison Method. Data were generated from discussions with 258 key stakeholders in 10 countries across Europe, exploring the historical, political, social, legal and economic factors that influence the patterns of social enterprise seen in each country.

Findings - The results identify the emergence of four social enterprise ecosystem types (Statist-macro; Statist-micro; Private-macro; Private-micro). These are used to explain the differences found in each of the 10 country's social enterprise ecosystems. The results are discussed in relation to evolutionary theory in social entrepreneurship and how 'genetic' and 'epigenetic' factors lead to the divergence of social enterprise ecosystems, and the impact that this has on the stakeholders and institutions that are present within them.

Originality/value - A typology of ecosystems is presented, which can be used by policymakers across Europe to understand how best to support their local social economies.

Keywords - Social enterprise; evolutionary theory; stakeholder networks; social networks; Europe. 


\section{The role of institutional and stakeholder networks in shaping social enterprise ecosystems in Europe}

\section{Introduction}

In recent years, a rich vein of comparative research has improved our understanding of the wide variety of forms of social enterprise seen internationally (see for example: Kerlin, 2006; 2010; 2013, Defourny and Nyssens, 2008; 2010, Galera and Borzaga, 2009; Doherty et al., 2009) and a range of typologies have been developed. However, knowledge of the wider systemic, cultural, socio-economic, political and historical factors that determine the types of social enterprise that emerge in a given context still remains underdeveloped. Each type differs according to the institutional context of a given country or region (Mendell, 2010), and our understanding of the emergence of these different 'ecosystems' and, in particular, how institutional and stakeholder networks influence the shape of their development is still in its infancy. In particular, geographical differences between regions can exist based upon the socio-economic and cultural contexts that exist within different regions of the world (Doherty et al., 2009) and these can be differentiated between developed and developing/transition economies and the differing socio-political clusters that exist within these [see Salamon et al., 2003) and Doherty et al., 2009) for a detailed description of these different clusters]. This paper draws upon prior research, which presented a theoretical framework for the emergence of the social enterprise ecosystems based upon metaphors drawn from biological evolutionary theory, in which an explanation for how the English and Scottish social enterprise ecosystems have developed differently over time due to varying historical (genetic) and institutional/environmental (epigenetic) factors (see Hazenberg et al 2016). This paper seeks to extend this research by practically applying the theory to the development of stakeholder and institutional networks across Europe and how they shape the different social enterprise ecosystems. We draw upon evidence gathered as part of a comparative analysis of the conditions shaping the development of social innovation and social enterprise in ten European countries, gathered from focus groups and in-depth face-to-face interviews carried out with stakeholders in each of the countries. 
The paper proceeds as follows: first of all, we discuss our theoretical framework and its suitability for the study of social enterprise ecosystems. This is followed by an overview of social network theory and pluralism in relation to social enterprise ecosystems. Following a brief outline of the research upon which the analysis is based, we discuss some of the substantive research findings and present a typology of social enterprise ecosystems depicting a rich picture of the networks that exist within each country. The article concludes by suggesting that greater pluralism should be encouraged for the development of flourishing, sustainable and robust social enterprise ecosystems. This research therefore makes an original contribution to knowledge in relation to utilising both evolutionary and stakeholder network theories to explain the emergence of different types of social economy across Europe, as well as supporting practitioners and policy-makers to better understand the ecosystems that they operate in or seek to support.

\section{Conceptualising social enterprise ecosystems using evolutionary theory}

The use and conceptualisation of 'ecosystems' in social enterprise research is not new and has been used in the past in several studies (Arthur et al., 2006; Grassl, 2012; Roy et al., 2015; Hazenberg et al., 2016). Evolutionary theory states that variation in species (in this case social enterprise) occurs due to three main factors: genetic variation, which is random, where new forms appear and their survival is dependent on how well their random changes are suited to the current environment; phenotypes, where environmental factors lead to variations in traits/behaviours and hence species; and epigenetics, where experience/environmental factors alter an organisms genetic coding leading to changes (During, 2014). Within biological ecosystems, everything that exists is a product of evolution within that system ('autopoiesis') (Maturana and Varela, 1987). However, organisms also have their own methods of interpreting external information and conditions, what can be termed their 'internal logics' (Van Assche et al., 2014). In essence this means that the interaction between organisms and their environments is a two-way process.

Hazenberg et al (2016) employed evolutionary theory to explore the development (and ongoing divergence) of the Scottish and English social enterprise ecosystems. Within this context, it was identified that 'genetic' and 'epigenetic' factors were responsible for the emergence of different dominant phenotypes in both countries, with Scottish social 
enterprises typifying the 'community enterprise' (collective/social) type and English social enterprises typifying the 'social business' (economic/individualistic) type (see Teasdale et al. 2012). The genetic factors were typified by each nation's shared history within the same state, and the similarities in company legal structures, and policy and politics that have occurred in the past. However, epigenetic factors (particularly policyrelated) were also influencing the development of each ecosystem both as homogenising and diversifying forces, with the overall effect being that the two ecosystems were diverging. It was hypothesised that the divergence of both ecosystems is leading to divergent genetic change, which in turn leads to the development of the differing dominant organisational types (phenotypes) outlined above (Maturana and Varela, 1987; During, 2014). Figure 1 illustrates this theoretical model.

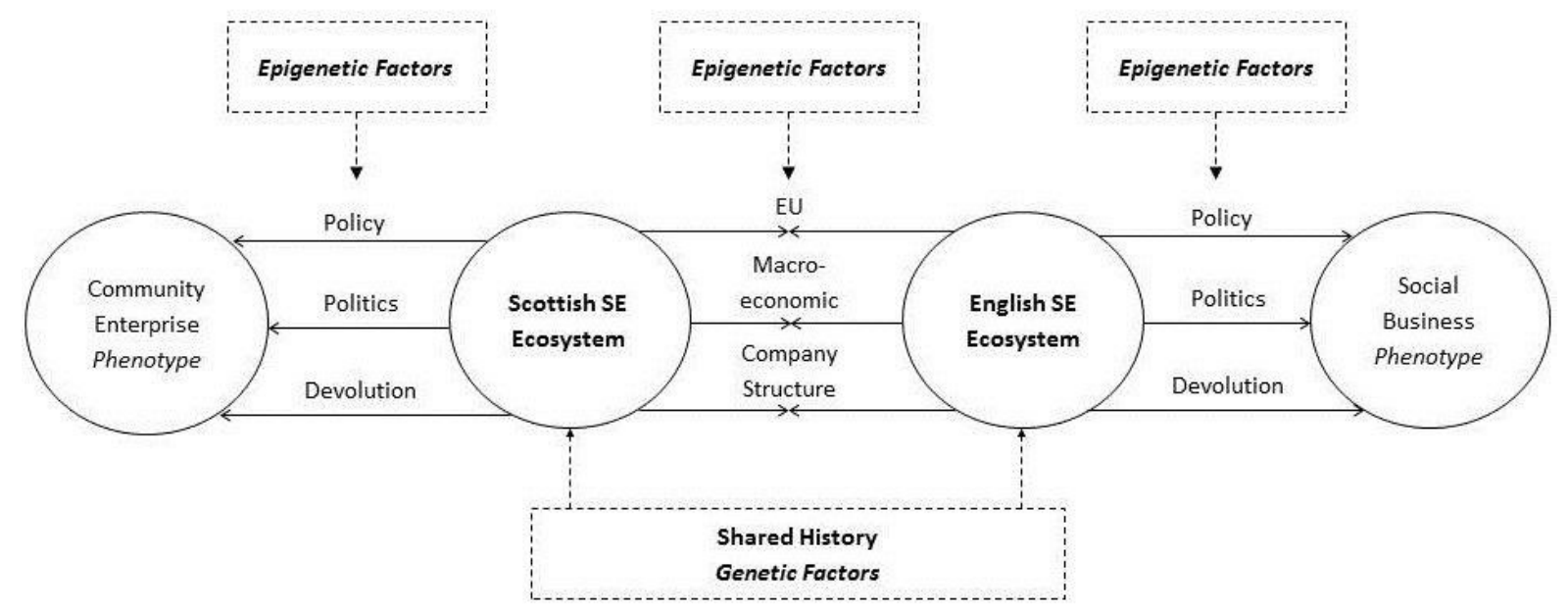

Figure 1: Comparative Development of the Scottish and English Ecosystems (Hazenberg et al, 2016)

Social enterprise, it could be argued, could be considered as a new sub-species of enterprise that has emerged over the last few decades from a variety of historical organisational ancestors, competing for survival in the turmoil of the socio-economic system (During, Van Dam and Salverda, 2016). However, while prior research has sought to theorise social enterprise ecosystems in this way, by necessity, the crucial role of human beings within such a social system has been over-simplified. Indeed, it is social interactions and communication with other different inhabitants of the ecosystem that also leads to change, as actors communicate and use this communication as a method of constantly reinterpreting their environment (Luhmann, 1989). This means that the networks contained within social enterprise ecosystems are fundamental to our 
understanding of how different stakeholder relationships affect the types of social enterprises that emerge (and their behaviour), especially if we are to further our knowledge of how the cultural, political, historical and geographical forces lead to 'fluid and contested' understandings of social enterprise (Teasdale, 2012) and hence different types of social enterprise ecosystems or clusters emerging (Doherty et al., 2009; Salamon et al., 2003). This paper seeks to contribute to this debate by exploring the enablers and barriers to social enterprise growth within ecosystems. In addition, it seeks to construct a typology of the social enterprise ecosystems that exist across Europe, based upon the presence of certain types of stakeholder, and the relationships/social networks that exist between them.

\section{Social network theory and pluralism in social enterprise ecosystems}

Granovetter's (1985) seminal work on embeddedness provides an important element in social network theory that relates to the understanding of how groups, institutions/organisations and individuals interact with each other within networks. Social network theory has been used to explain how the positionality of actors/organisations within a network or ecosystem acts as both an enabler and constraint on their behaviour, and hence mediates their development and the successful pursuit of their goals (Brass, 1984; Mehra, Kilduff, and Brass, 2001; Qureshi, Bistruck and Bhatt, 2016). The relationships between actors/organisations also mediate the flow of resources including financial and emotional (Jack, 2005) resources; and knowledge and information (Uzzi, 1996). This provides an interesting and useful analytical framework from which to explore the development of social enterprise ecosystems as it is the interactions between institutions (i.e. political, legal, financial, educational); groups (private, public and third sectors and the networks/groupings within them); organisations (social enterprises themselves); and individuals (social entrepreneurs, politicians/policy-makers, academics, lawyers/accountants and so on) that build and shape the ecosystem through their interactions and exchange of resources (financial or otherwise). Indeed, the growth of sustainable enterprises (and hence social enterprises) does not occur within a vacuum, but within a wider political and socio-economic environment (Zafeiropoulou and Koufopoulos, 2013). This makes the study of the relationships between different stakeholder groups fundamental to understanding how social networks and communication shape the development (Luhmann, 1989) of a social 
enterprise ecosystem, and hence how different paradigms and narratives can emerge in different geographical locations to explain social enterprise.

The use of social network theory approaches to explaining the development of social enterprises is, of course, not new. Zafeiropoulou and Koufopoulos (2013) utilised social network theory to explore the development of social franchising within social enterprise and identified that relational network embeddedness and relationship development characterised by trust, reduced conflict, collaboration, reduced power dynamics and flexibility were crucial to the development and performance of social franchises. Qureshi et al. (2016) utilised social network theory to understand the development of social entrepreneurship in China and identified that those entrepreneurs that had more pluralistic social networks were more likely to reject conformism and act innovatively. Smith and Stevens (2010) explored how geographic space and the scope and reach of the social enterprise affected levels of embeddedness, engagement with social networks and hence shaped social entrepreneur behaviour and actions. However, the prior research outlined above utilised social network theory to explain the behaviour of individual organisations/entrepreneurs, and did not provide a macro-level explanation for the development of social enterprise ecosystems.

Furthermore, when seeking to understand the development of social enterprise ecosystems at the macro-level through the lens of evolutionary theory, it is essential to understand the impact that stakeholder networks and interactions at the meso- and micro-levels can exert. Indeed, when exploring how paradigmatic changes in the field of social entrepreneurship are driven, Nicholls (2010) identified how certain groups of stakeholders (governments, foundations, fellowship organisations, and formalised networks) wield significant influence through the resources that they hold, their network embeddedness and their access to power. Such stakeholders can utilise these resources to shape discourse around social entrepreneurship and hence drive paradigmatic shifts in the field (and thus within ecosystems) (Nicholls, 2010). These stakeholder groupings can therefore wield disproportionate power and effect positive and negative changes on social ecosystems. For instance, scholars have contested whether the 'Big Society' discourse in the UK and the focus on making the social economy more 'enterprising' has been positive for the social enterprise sector or not (McKay et al., 2014; Dey and Teasdale, 2016). The types of stakeholders present in an ecosystem, their relative power and 
embeddedness, and their social networks are therefore powerful factors in shaping the social enterprise ecosystem.

There is also a significant strand of research that argues that informal institutions such as culture, heritage, and normative values are significant factors in shaping economic behaviour (Baumol, 1990; North, 1990; Williamson, 2000; Puumalainen et al., 2015); furthermore, these informal institutions are shaped by social networks that mediate trust, reputation, collaboration, power dynamics, commitment and shared norms (Zafeiropoulou and Koufopoulos, 2013; Qureshi et al., 2016; Doherty et al., 2009). While social networks within social enterprise ecosystems appear critical as both mediators of stakeholder behaviour and interpretation of logics and discourses (Luhmann, 1989; Van Assche et al., 2014; Hazenberg et al., 2016), the distribution (and potential concentration) of power between stakeholders, as well as stakeholder diversity within the ecosystem, is also an important factor in shaping its development. The power of certain stakeholders to shape discourse can also create networks within the ecosystem that compel individuals/organisations to act or think in certain ways (Dey and Steyaert, 2014).

\section{Methodology}

This article draws upon findings from a mixed method and comparative European Unionfunded research project. The overall project aim was to compare and analyse the conditions under which social innovation and social entrepreneurship originate and develop in ten European countries and three non-European comparators, and assess whether such initiatives offer a sustainable contribution to solving social challenges. The research took place across 10 different partner European countries (Austria; England; France; Germany; Italy; Netherlands; Poland; Scotland; Serbia; Sweden) and involved 117 one-to-one interviews and 20 focus groups ${ }^{1}$ involving 141 participants. The total number of participants engaged overall in the research was 258 social enterprise stakeholders. These data were then used to produce 10 stakeholder maps - one for each country designed to identify the key stakeholders involved in each country's social enterprise ecosystem and the types of relationships that exist between them. The stakeholder maps

\footnotetext{
${ }^{1}$ Focus groups were required to have a minimum of six participants so as to ensure representation of stakeholder groups/views. In reality, this minimum number was not always possible to achieve.
} 
were later collated and analysed to identify differences and commonalities between them.

The data gathering process took place in three phases: firstly, two focus groups were undertaken within an identified city-level (local) location in each country to explore the enablers and barriers present for social enterprise ecosystems. One of these focus groups involved local social entrepreneurs, while the other focus group involved other key stakeholders (local government; policy-makers; social enterprise support organisations). These focus groups also enabled the identification of national stakeholders relevant to local ecosystems who could be interviewed during the second phase utilising a semistructured interview schedule iteratively developed out of the focus group data. The second phase then involved these semi-structured interviews taking place with the key stakeholders identified within the focus groups (who could be from the public, third and private sectors). Data were then analysed along with the focus group data in order to identify qualitative themes and stakeholder networks.

The analysis of the qualitative data was undertaken iteratively, grounded in prior literature and the individual researchers' own knowledge of their country's social enterprise ecosystem. The method employed to analyse the transcripts of the participant focus groups and individual semi-structured interviews was 'Constant Comparative Method' (CCM) (Glaser \& Strauss, 1967; Lincoln \& Guba, 1985) which has been successfully applied in previous studies across a wide range of disciplines including social venture creation (for example, see Haugh, 2007). The seven themes to iteratively emerge in relation to the barriers and enablers of social enterprise ecosystems were: procurement policies/regulation for social innovation; financial activities for ecosystem growth; inclusive labour market practices; collaborative stakeholder systems; training and education in support of ecosystem growth; impact and dissemination; and system drivers. The research teams across the 10 partners also identified key stakeholder groups within the ecosystem and the relationships that existed between them, on the basis of political/policy links; regulation/legislation; partnerships; advocacy; procurement; funding; education; investment; trade; Corporate Social Responsibility (CSR); and commissioning. 


\section{Results}

The analysis for each country of the interview and focus group data, as well as the stakeholder maps ${ }^{2}$ provided the research team with a rich picture of the networks that exist within the social enterprise ecosystems of each country. Seven key themes emerged: procurement policies/regulation for social innovation; financial activities for ecosystem growth; inclusive labour market practices; collaborative stakeholder systems; training and education in support of ecosystem growth; impact and dissemination; and system drivers. The results indicate the existence of four social enterprise ecosystem types, which we have identified as follows: (A) Statist-macro; (B) Statist-micro; (C) Privatemacro; and (D) Private-micro, and each is discussed in turn. While this data provides strong evidence for the overall ecosystem type identified for each country, it should also be noted that generalised trends have been identified within each type and that each has its own characteristics.

\section{Type A - Statist Macro (Poland; France; Serbia; Austria)}

This type is characterised by a reliance on state institutions for funding and policy support, and this support invariably emerges from national government or transnational (usually European Union) sources. There are often close links between third sector and public sector stakeholders that generally takes the form of funding support (grant and procurement), policy mechanisms and legal/regulatory frameworks. For those countries that have smaller third sectors and less-developed civil societies (Poland and Serbia) the lack of localism is marked. There is also for some countries (notably Serbia) reliance (mainly in the form of funding and lobbying) on support from international NGOs (i.e. Ashoka) that seek to promote the social economy as a means of solving social problems (although this also exists in other countries). This country-wide support from national and supra-national institutions creates a relatively homogenous social enterprise ecosystem as the conditions present limit diversification. In these countries procurement and regulation policies are characterised by a lack of: localism (particularly in Poland and Serbia); a lack of focus on social and environmental values (or ignorance of them); and a need for education of procurement officials and commissioners around the value of the social economy. In Serbia, the government's procurement focus is only targeted at narrow

\footnotetext{
${ }^{2}$ These stakeholder maps and the descriptive quantitative analysis of them can be found in the Work Package 4 Stakeholder Networks report available online at http://www.fp7-efeseiis.eu/
} 
sections of the social economy (work-integration) and while there is a desire to move towards local funding this is not always delivered. Indeed, it is argued that as much of the funding for social enterprises comes from the EU the focus of funding is too grant focused without sufficient support for capacity building, scaling and sustainability:

"Currently the state supports SEs through direct funding with no obligations, while it would be better to support the SEs to develop themselves. Start-up support is important, but SE cannot be financed throughout their life." (Serbian Participant).

In relation to financial support for social enterprises the Statist-macro countries were characterised by centralised grant funding programmes (as was shown by Serbia earlier) that were focused on funding social enterprise activity rather than sustainability. In addition, there was a feeling that support lacked a staged focus, that is the creation of funding streams for different stages of a social enterprise's development (i.e. start-up; scaling/sustainability; consolidation). In Austria this was slightly more nuanced in that stakeholders also argued that poor regulation discouraged the growth of private funds (i.e. philanthropic foundations and/or investors) from supporting the social economy, which resulted in programmes that were too output focused. These countries were effectively characterised by an under-developed social investment market and an overreliance on state and/or

"The money is inefficiently spent on social problems. While money is invested in the right projects, the way this is done is old-fashioned. The beneficiary group is seen as an object of support and not as subject/actors of change. Often, investments are based on statistics and impact measurements only. Instead of questioning what the outcome of the investment could or should be, we only ask how many people were reached by the measure." (SE Practitioner, Austria)

Statist-macro countries were also characterised by the state's desire to utilise the social economy in labour-market integration activities (especially in countries of high unemployment such as Serbia and Poland). This use of work-integration social enterprises (WISEs) in an attempt to promote more inclusive labour market practices was driven by both national state institutions and European funding. However, while the latter helped to do this at local levels, a lack of localism (especially in Poland and Serbia) hindered the effectiveness of this (with Serbian stakeholders arguing that this was a characteristic of the lack of sustainability focus). In Serbia this was driven centrally by 
the Ministry for Labour, Employment, Veteran and Social Affairs; while in Poland the lack of support for such activity at a local level was lamented. The Austrian context was one that involved more local engagement with civil society as it was felt that working to engage vulnerable people in the labour market was a "traditional model for social enterprises". However, this new model was not necessarily traditional as many new social ventures were related to immigration and/or started by migrants themselves (hence representing a new section of civil society):

"It is important for the new law to move from the perspective of employment of vulnerable groups to real social entrepreneurship." (Serbian Participant)

The lack of localism outlined above is also evident in Statist-macro countries in relation to the development of collaborative stakeholder systems. While in some countries, (notably Serbia) collaboration between dominant stakeholders is almost non-existent; in others (such as Poland) there is at least strong collaboration between national and European stakeholders but a lack of national/local stakeholder collaboration. Therefore, in Serbia the European Union is seen as a crucial element in driving social enterprise ecosystem growth. Conversely, the Austrian context is one in which stakeholders feel that national institutions lack initiative in engaging with European policy (both in shaping and implementing it) and that they are too passive in developing collaborative networks.

Training and education to support ecosystem growth was also an issue that was typified in Statist-macro countries by a commitment in the formal education system (under 18 years of age school education) to educate pupils regarding social entrepreneurship. Indeed, this is implemented in Serbia, Austria and France, while Poland has more diversity in entrepreneurship education depending upon the local municipality. There was also a commitment amongst all countries (but again most notably Serbia and Austria) to provide training to nascent social entrepreneurs (through the National Agency for Regional Development in Serbia; and through NGOs in Austria including Impact HUB and Ashoka). Social entrepreneurship education within universities tends to still be in its infancy, but is developing even if this is often restricted to the major urban centres.

Finally, in relation to the impact and dissemination of social enterprises and the drivers of ecosystems within countries, Statist-macro nations tend to lament the complexity and difficulty of measuring social impact. This led to a diversity of strategies emerging with some countries (Serbia) seeking to use official data (particularly in relation to labour- 
market integration) to evidence impact, while others (Austria and Poland) see the complexities as too great for smaller social enterprises to deal with. This was an area where it was difficult to identify homogeneity of opinion within the type, or within individual countries, and so acts as somewhat of an outlier in this analysis.

"They should list all stakeholders and guess what the impact of their initiative for each stakeholder is. They should try to quantify the impact and calculate it in Euros". (Academic, Austria)

"Measuring social impact is difficult. You can try to measure e.g. Employees' satisfaction; periodically you can measure the satisfaction of the residents in the given region, the level of knowledge about the SE and observe how it is changing." (SE Support Organisation, Poland).

\section{Type B - Statist Micro (Scotland; Sweden)}

This type is again reliant on state institutions for funding and policy support, however, support is much more embedded at the local level through procurement policies and community initiatives. Indeed, national policy and funding programmes targeted at the social economy are limited (or non-existent) leading to local diversification of ecosystems across the nation-state. Support from international state institutions is also embedded at the local level through European funds such as the European Social Fund (ESF) and European Regional Development Fund (ERDF). Nevertheless, the majority of financial and policy-regulatory support emerges from local authorities/municipalities, which leads to much more community focused social enterprises emerging, but also leads to a fragmentary and heterogeneous landscape emerging nationally, as some regions/localities support their social enterprise ecosystems more than others.

Amongst the two Statist-micro countries procurement and legislation were seen as potential enablers of social enterprise at the local level, but because of the highly decentralised natures of states, interpretation of and a desire to do this were dependent upon individual local authorities. In Scotland, this was exemplified by the sporadic use of 'Community Benefit Clauses'; while in Sweden a lack of understanding of what social entrepreneurship is and a lack of promotion of social enterprise from central government at a local level has led to minimal use of social enterprise in public procurement. In addition, in both countries, procurement legislation and a focus on larger-scale, cheaper 
providers have made competing for public service contracts difficult for social enterprises. This has been particularly exacerbated in Scotland due to austerity and cuts in public expenditure:

"The big problem is obviously the fact that there is no overarching support structure and no legal framework adapted solely for social entrepreneurs. The current system is built upon the structures of the private, public and civil sector, something that unfortunately has shaped and dictated the conditions for the whole SE sector." (Association of Local Authorities and Regions, Sweden)

"I think it's [procurement process is] not even skewed just towards private businesses, it's skewed towards big business." (SE Support Organisation, Scotland)

Scotland and Sweden also had similar approaches to the financing of social enterprise growth involving state subsidy, with both models tending towards subsidised state loans combined with (in the Scottish case) grants from central government through agencies including Firstport and Social Investment Scotland. In Sweden the subsidy is also from central government and delivered through the 'Almi' national investment fund. The concern in the Scottish context is that a large amount of this funding is taken by administration/infrastructure and that minimal amounts actually make it to frontline organisations:

"the interesting piece of research...would be to look directly at where the government actually puts its money in towards social enterprise. And you will, I think, discover that an awful lot of it goes into the supporting organisations, support organisations based in Edinburgh and Glasgow." (Business Support Stakeholder, Scotland).

In the Swedish context the funding provided is not solely for social enterprises, but all ethical businesses and many social enterprise applications are rejected due to concerns over sustainability. This means that often, while loan funding does exist, it is effectively not attainable by many social enterprises.

Both Scotland and Sweden take similar approaches in utilising local SEs to engage with vulnerable unemployed groups within communities. Indeed, in Sweden the WISE sector is probably the largest social enterprise sector in operation. In both countries their importance in delivery social integration is recognised, along with the need for the state 
to subsidise this locally to ensure that the WISEs can be competitive. However, funding pressures in Scotland are putting such support at risk, along with competitive tendering processes and Service Level Agreements (SLAs). This engagement between the third and public sectors at a local level is perhaps one of the stronger indicators of the Statist-micro type.

"The best way we can assist social enterprises to employ vulnerable members of the labour market is to offer more wage subsidies that can secure long-lasting employment. Moreover, we need to develop a solid support structure for tutoring and professional guidance. In this respect, the Public Unemployment Service plays an important role. However, when it comes to economic support I think it could be better at increasing its compensation for long-term unemployed people." (Agency for Economic and Regional Growth, Sweden)

The localism agenda present in both the Swedish and Scottish social enterprise ecosystem is typified in the stakeholder networks that exist. Indeed, both countries have extensive and collaborative networks in existence at local levels (even if this is often local authority/municipality dependent). While in Scotland this is supported by strong European networks and funding (that aims to develop closer national/local links), as well as support from central government; in Sweden, support and collaboration at the national level is less prominent. The desire for partnership between the local state and the third sector/communities is typified by the 'Community Asset Transfer' (CAT) programme in Scotland, in which social enterprises can take over the management of a community resource from the local authority:

“...organisations, individuals or businesses that have a productive idea for the use of that particular resource can be invited to make a proposal and take over the resource if the LA approves their plan... If you have a productive idea for the use of that particular resource, then come to us and talk to us about it and see if we can jointly develop it." (Local Authority, Scotland)

Finally, in assessing the impact and disseminating the activities of social enterprise ecosystems, Statist-micro countries are similar to their -macro counterparts in that social impact measurement is seen as costly and difficult. However, it is also recognised that assessing such impact can act as a powerful driver of systemic change, with new thinking required by governments around how much money can be saved through preventative 
funding of social problems (and hence provision via social enterprises). Such a financially orientated approach to measurement was typical in both Scotland and Sweden, and perhaps epitomises the significant role of local state authorities in the ecosystem. However, in driving further systemic change it was argued that austerity and the shrinking state, as well as the passivity of some local authorities towards social enterprise, could have negative future impacts on the ecosystems of both countries. It was also acknowledged that such changes also presented the opportunity for greater devolution of responsibilities to communities, and hence a more localised social enterprise ecosystem.

\section{Type C-Private Macro (Germany and England)}

The Private Macro type is typified by a lack of state funding (at a national level) for the social economy. However, there is national policy support aimed at developing the social enterprise ecosystem to become more market orientated and to operate as social businesses. This focus on professionalising the third sector means that increasing amount of funding support in the form of investment is sought from private/social investors and legislation is passed that seeks to encourage the development of social enterprises locally and their involvement in public procurement. Despite this focus their remains grant/project funding for development, mainly available through international state institutions (European Union). However, there is an ongoing shift towards developing the ecosystem into one that relies more on market trading mechanisms (including in competitively tendered public service delivery) and the shifting of public services from the public sector into the third sector (i.e. public service spin-outs in England). This again tends to homogenise the ecosystem to a degree, although this occurs through market competition as opposed to the policy mechanisms seen in the Statist Macro type.

For Private-macro countries procurement policies and regulation were seen as in need of reform to enhance the social enterprise ecosystems, but this reform was not viewed as significant. Suggested reforms mainly focused on more attention to social value; bolder procurement/commissioners; increased marketisation (Germany only); as well as greater localism and collaboration between communities and local authorities/municipalities. In addition, it was also argued that a greater focus on allowing smaller organisations to compete in the procurement process was required: 
"In terms of economic development at [local authority] I think they prioritise getting the bigger companies up and running and I think a conversation about policy and supporting smaller SEs might be helpful." (Social Entrepreneur, England)

In relation to the financing of ecosystem growth there was some variation within the Private-macro, with England leading the world in the development of a social investment market. In Germany this was not so well developed, and organisations reported difficulty accessing private/social investment due to perceptions of the lack of sustainability of social enterprises. However, problems securing investment still existed in England and it was argued that gaps in both countries still existed in the provision of staged investment to social enterprises, especially in the $€ 100,000-€ 500,000$ turnover range which was called the "valley of death" by one German SE stakeholder, to describe the point at which the level of investment is too high for many sponsors, but too small or risky for impactoriented investors. The solutions to this revolved around greater state subsidised support in the form of grants for socially innovative start-ups; but also included the development of products that were better suited than current legal/financial frameworks to supporting social enterprise ecosystems. There was also an acceptance (particularly in England) that it was necessary for social enterprises to secure the majority of their money from trading to ensure sustainability.

When compared with the focus on inclusive labour market practices in both the Statist types (and particularly in the Statist-micro countries); inclusive labour market practices were much less important amongst interviewees from the Private-macro countries. In Germany the issue of inclusive labour-market integration was not a major theme within the data, although it is possible to link this lack of focus to the lack of focus on social value in the procurement process (as outlined earlier). This was also the case in England, where inclusive work-integration did not emerge, and where government policy in reducing unemployment tends to focus on engaging with larger private organisations and supporting individuals to become 'labour-market ready' and into employment quickly.

Private-macro type countries share similarities with the State-macro (desire for greater localism) ecosystems; however, the difference lies within the amount of existing private sector involvement in the ecosystem and the more pluralistic networks that exist (with the exception of Austria). Nevertheless, despite this greater pluralism, stakeholders still want to see greater collaboration across local areas, where participants argued that there 
was often a lack of truly integrated collaboration at a local level. This lack of collaboration was seen as one of the reasons behind resource scarcity, as money was spent on several programmes targeting the same social problem due to a lack of coordination. However, it was also recognised that there was a tension between a marketised approach to the social economy, as seen in Private-macro countries, and collaboration, as competition invariably reduced willingness to share:

"Local government here needs someone to advise and integrate us into the wider community. There are things we can learn and do... We need someone at local level who can give integration, guidance and advice." (Social Entrepreneur, England)

"Money is abundant. If we bring together all things, which kind of demands exist, which instruments are in place, which social organizations are in the area established, and only focus on meaningfulness, we would drown in money. Right now we finance everything double- and three-fold. There is this one social organization offering this that is almost unable to survive, another one offers something similar and only nearly survives. If we could put this together, coordinate, then everything could be easily financed." (SE Stakeholder, Germany)

In contrast to the efforts to promote social entrepreneurship education at all levels of the education system in the Statist-macro (and to a lesser degree) the Statist-micro countries; Private-macro countries were characterised by their lack of focus on social enterprise education (certainly at the compulsory education level). In England, while some universities had engaged deeply with social enterprise education, this was often done in a piecemeal way (i.e. specific modules) rather than strategically through the development of whole degree programmes and post-graduate qualifications. In Germany the issue of social enterprise education was barely discussed by the participants. The lack of focus on social entrepreneurship education (particularly in schools) was lamented and seen as a missed opportunity for promoting social enterprise and more inclusive societies:

"Social enterprise and social entrepreneurship should be taught as part of Business Studies, as part of Careers, as part of Humanities, introduced into history, geography, all sorts of subject matter......and equally in those kind of social subjects, the role of 'business' in advancing public benefit should also be recognised." (SE Stakeholder, England) 
Finally, in relation to impact, dissemination and driving systemic change, the Privatemacro countries were characterised by a recognition of the importance of impact measurement in supporting the social enterprise ecosystem to grow, but a recognition of the difficulty of measuring this and a distrust of the quantitative methods (e.g. Social Return on Investment - SROI) that currently exist to do this.

"So I think there is something very critical in not just thinking about social impact measurement for social entrepreneurs but actually changing how we report and account for value in the sector......the key for me is they absolutely should measure what they are doing. You know, if they're in this work to make a difference, you know, they need to know that they're making a difference. It just seems like a fairly obviously point to me. If you are not making a difference, don't do it." (SE Stakeholder, England)

This theme of measuring social value was also present in the Statist types and reflects the difficulties that organisations have in demonstrating the social impact that they deliver. In addition, when focusing on driving systemic change and the growth of social enterprise ecosystems, both countries recognised that income diversification for social enterprises was key to future growth, especially given the uncertainty around state funding and welfare provision, which was of particular concern in England.

\section{Type D - Private Micro (Netherlands and Italy)}

The Private Micro type is exemplified by a relatively low level of state funding and a reliance upon market trading mechanisms. However, this is not driven through national state policy or (to a degree) through national private/social investors, but is instead more locally driven through local and regional associations, cooperative movements and funding bodies and, to a lesser degree, through local authorities/municipalities. This again creates a more heterogeneous social enterprise ecosystem, albeit one that has fewer relationships with the local state and more relationships with other third sector organisations and local businesses. This is a localist approach, particularly in contrast to the Statist Micro quadrant.

Private-micro countries were both characterised by a critique of both procurement and of public policy focus on economic value over social value. It was argued that such procurement policies made it difficult for social enterprises to compete for contracts. In 
addition, in Italy it was argued that there was a tension between the procurement policies implemented by the state (economic focused) and the new directives emerging from Europe (focused more on social/environmental value):

"Practically seen, could public procurement be improved by 'checking a specific box' in which you can choose a social procurement trajectory? That would be ideal." (SE Stakeholder, Netherlands)

In relation to financing activities for ecosystem growth, both Private-micro countries identified difficulties in accessing funding and/or investment, and both attributed this to the inadequate legal and financial frameworks that existed (legal organisational form; taxation; investment/financial frameworks). Again, both countries also recognised the need for social enterprises to be able to access different forms of finance at different stages of development (grants and seed funding during the early-stages of social enterprise development; investment finance with grace periods for the scaling phase). Indeed, this was seen a critical to efforts to help social enterprises to compete with larger and better capitalised private sector competitors. Conversely, however, there was also recognition that the social enterprise sector was not a homogenous entity, but actually consisted of different types that all had different needs.

Interestingly, there was considerable difference between the approach to inclusive labour market policy and practice in Italy and that of the Netherlands. The Italian case was seen as internationally pioneering, based upon Italy's long history of cooperatives and work-integration programmes. Indeed, it was also argued that their pioneering approach to inclusive labour-market integration was not fully understood by European policy-makers (according to one SE support organisation in Italy, there was a belief that Type B social co-operatives were seen to 'distort competition') and this hindered the growth of the sector, and potentially the spread of similar ideas elsewhere in Europe. In the Netherlands, while quotas exist for the hiring of people with disabilities, this does not transfer into wider work-integration programmes and while policies do exist (for example Social Return in Procurement ${ }^{3}$ ) this was often seen to disadvantage social enterprises and other smaller organisations. Inclusive labour market policies were therefore not well-developed in the Dutch context.

\footnotetext{
${ }^{3}$ See https://www.utrecht.nl/werk-en-inkomen/social-return/ for further information.
} 
Both countries had very well-developed collaborative stakeholder networks at the local level, but felt that engagement with national institutions and European institutions and funds could be better. Indeed, in both countries it was felt that European policy did not always facilitate the establishment of well-networked ecosystems and that it often seemed far removed from the realities on the ground:

"Europe is far away from here in practice. And I never have had anything to do with the province in the one and a halfyears that I have been here at the municipality. I do connect to the national government, but in a minimum way. My 'reality' is mostly here. When talking about an enabling environment, I experience other governmental organizations mostly [in an] abstract way, in a way I do have to reckon with them, but I do not have a relationship with them. You see? But I do have a lot of relations with people and companies here in the area. That is my enabling environment." (Academic, Netherlands)

In the Netherlands localised collaborative stakeholder networks were highly embedded, with the development of the 'sharing economy' at a local level seen as a key innovation of the social enterprise ecosystem. In Italy, while local networks were not perhaps as well embedded as those in the Netherlands, the long tradition of social enterprise and cooperatives in Italy meant that local networks were strong. This was seen as crucial to the future of the ecosystem in Italy, as austerity would lead to the end of the 'traditional welfare model' and social enterprise could fill this gap through the development of innovative solutions and networks:

In relation to training/education around social entrepreneurship, both Private-micro countries were seen to have poor entrepreneurship education in the school system, although there were pockets of excellence in the higher education sector. Learning from best practice international education programmes was seen as crucial to improving this situation. In addition, it was argued that if awareness of social enterprise was to be increased and the professionalization of the sector to be achieved, then a more outcome focused approach to social enterprise education needed to be implemented in school education systems:

"It [social entrepreneurship education in schools] is a huge issue......The Global Entrepreneurship Monitor (GEM) shows the difficulties in the Italian situation. We 
do not encourage people to take the risk anymore, in both family and scholastic context." (SE Support Organisation, Italy)

"What type of mentality is important and what type of skills should be developed at primary and secondary school? Answers are emerging through discovery learning. There are already some very interesting international programs that stimulate discovery learning and entrepreneurial learning in secondary and primary schools. These types of programs should be encouraged, supported and funded everywhere." (Social Innovator, Netherlands)

In addition, training and professional education courses for nascent and existing social entrepreneurs would also be critical, especially if connected in to the good existing local networks within the ecosystem.

The social impact measurement sector in the Netherlands was still seen as being in its infancy in terms of the development of appropriate tools. Qualitative measures (such as story-telling) were seen as very important. When exploring the systemic drivers of future growth in their respective social enterprise ecosystems, both Private-micro countries identified enhanced collaboration and networking; better policy and procurement enablers; improved access to capital; social enterprise education and dissemination of impact stories (and the role of technology in this); and the role of social enterprise in answering the welfare crisis as all opportunities for the growth of social enterprise moving forwards.

\section{Discussion}

\section{Social enterprise ecosystems and stakeholder/social networks}

The results presented have provided evidence for the existence of four different social enterprise ecosystem types across Europe: Statist-macro; Statist-micro; Private-macro; and Private-micro. This typology contains four sub-quadrants that provide subtle differences in the main features of each type, which are based upon the level of state, third and private sector stakeholder engagement, as well as the relative geographic placement of the ecosystems (local; national; international). This theoretical framework posits that each ecosystem type has its own: traditions and traits (genetics); environmental conditions (epigenetics); which combine to affect the emergence of different organisational forms (phenotypes) (Hazenberg et al., 2016). 
Nevertheless, it is also important to stress that our typology only provides a general template for the different ecosystems that exist across Europe, and should not be mistaken for holistic descriptors of social enterprise activity within each state. Merely, they represent a guide to the type of ecosystem that each country was seen to have. Indeed, the boundaries between types are both blurred and fluid. In some aspects this can be identified in the similarities and differences that exist between the Austrian ecosystem (Statist-macro) and its fellow type countries (Poland, France, and Serbia) but also other countries of different ecosystem types, including Germany and England. In making this distinction, the research offers support to the prior research by Hazenberg et al. (2016) that demonstrated how social enterprise ecosystems and the organisations that reside within them can (and do) change over time in relation to different political, socio-economic, and historical-cultural factors. In addition, such differences are in part explainable by the different historical, political and socio-economic factors within countries of the same ecosystem type (e.g. the former Soviet model transition countries of Serbia and Poland and the European welfare state model of Austria) (Doherty et al., 2009).

\section{Four normative social enterprise ecosystem types}

During et al. (2016) identify that social enterprises are competing within the turmoil of the socio-economic system for survival. However, this research identifies that while such competition exists, it is in places countered by a growing network of collaborative stakeholders and the emergence of strategic partnerships within the social enterprise ecosystem. This is what the research has identified as the 'Pluralistic Zone' and the development of ecosystems (across any of the four types) towards greater pluralism should be deemed the 'ideal scenario' for the development of flourishing, sustainable and robust social enterprise ecosystems (see Figure 2 below). This is because greater pluralism in the form of diverse income streams, wider stakeholder engagement; evidence-based policy interventions; cultural relativism; and balanced sectorial involvement provides social enterprise ecosystems with the ability to both withstand negative environmental conditions (economic downturns; political volatility) and to improve organisational performance. This diversity will also allow for increased heterogeneity in the social enterprise 'gene pool' (During et al., 2016) and increase communication in order to facilitate positive change, learning and the continual 
reassessment of logics (Luhmann, 1988). It is such pluralistic networks that allow social enterprise ecosystems to understand their environment and see the 'truth' (Dey and Steyaert, 2012), resist dominant discourses (Jones et al., 2015), and think and behave independently and innovatively (Dey and Steyaert, 2014) by creating areas of low power distance (Puumalainen et al., 2015) and increasing trust and collaboration (Zafeiropoulou and Koufopoulos, 2013; Qureshi et al., 2016).

The typology presented (Statist-macro; Statist-micro; Private-macro; and Private-micro) is outlined in Figure 2, with the four types identified in relation to their relative positions against two axes: local/international; and state/private. As was outlined earlier, each type consists of different dominant stakeholder groups and discourses which are the result of both historical factors (genetic); environmental factors (epigenetic); and the social relations that exists between organisms (institutions, organisations and individuals) within the ecosystem. The characteristics of each type is summarised as follows:

Statist-macro: This type is characterised by a reliance on centralised state institutions at either a national or international level, in which policy/funding mechanisms are utilised to support the development of social enterprises to deal with social problems. The ecosystems present within this typology are often less commercially sustainable as they are reliant on grant and/or directed funding and are homogenous in the types of social enterprises that emerge (particularly around WISEs). There is a lack of localism and a lack of collaboration between stakeholders at the macro- and micro-levels, but relatively strong formalised social entrepreneurship education in schools.

Statist-micro: while this type is also reliant on state institutions for funding and policy support, this is much more embedded at a local level through procurement and community initiatives. There is also widespread use of central state and European funding for local social enterprise support, with the former often being in the form of subsidised loans rather than grants. The localised nature of the ecosystems present within this typology leads to heterogeneity in the ecosystems present. Again, WISEs are common as the state sees social enterprises as a robust labour-market integration method for vulnerable groups.

Private-macro: This type is characterised by a lack of state financial subsidy; however, the state does utilise policy in an effort to assist social enterprises to become more market 
orientated. Funding is therefore providing through competitive contracts and social investors, although the focus on social value in procurement varies at a local level (despite national attempts to encourage this. Inclusive labour-market policies are less common within this typology and formalised social enterprise education in schools is almost non-existent.

Private-micro: Like the private-macro type, the private-micro type seeks to promote greater marketisation of the social enterprise sector and encourage income diversification. However, this is not driven at the macro-level by state policy, but at the local level by regional associations and local government. This type is characterised by capitalisation problems for social enterprises and diversity in policies to encourage labour-market integration. The formal education of social entrepreneurship in schools is almost non-existent and collaborative networks between the micro- and macro-levels is poor.

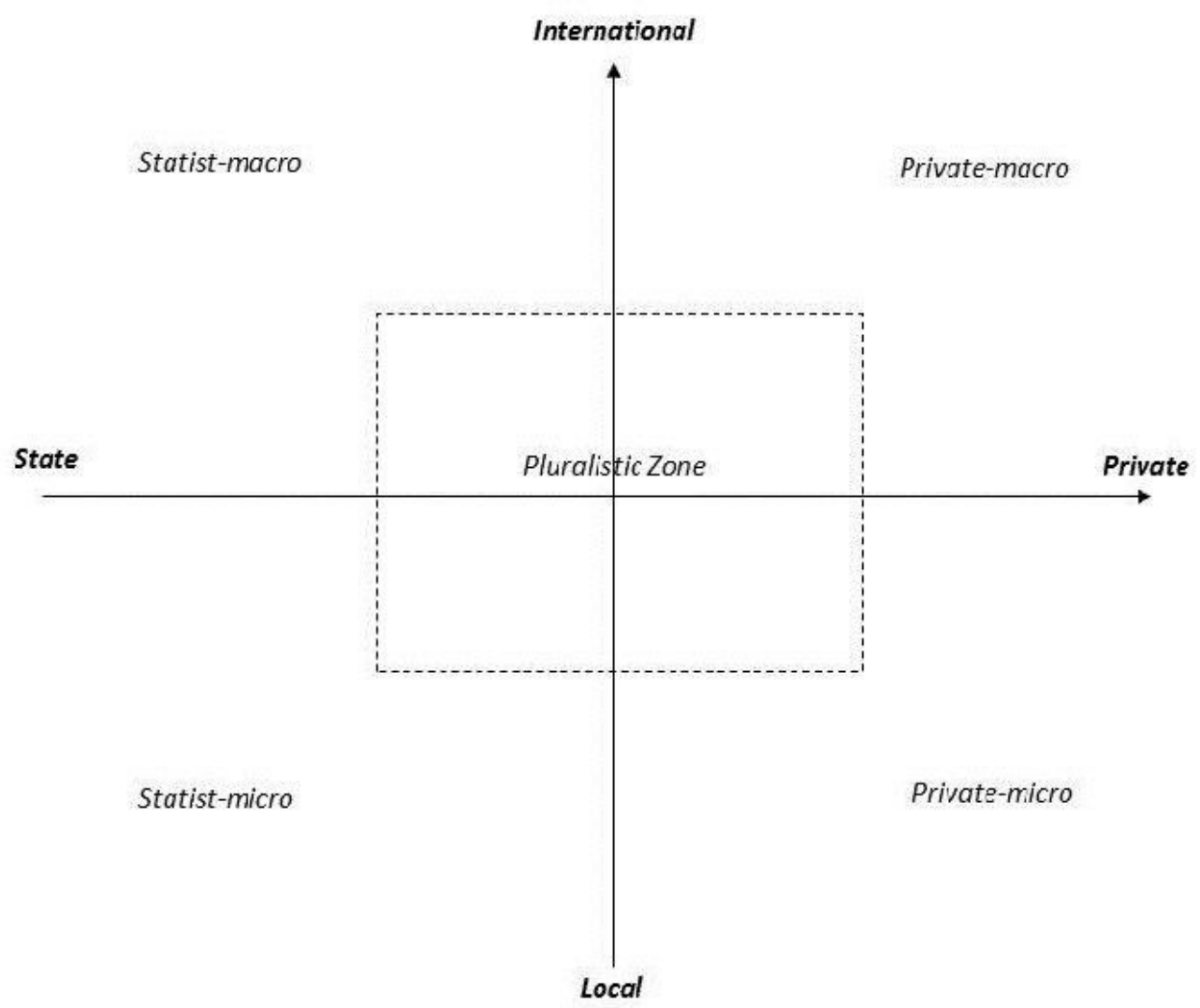

Figure 2: Social enterprise ecosystem typology 


\section{Conclusion}

The evolution of an ecosystem and resulting emergence of different organisational types within it ('autopoiesis') (Maturana and Varela, 1987), can assist those supporting social enterprise ecosystem development (e.g. policy-makers) to understand the types of ecosystem that they are supporting and what their development needs may be. The internal logics and perceptions that exist within an ecosystem, as evidenced here in the interview data and stakeholder maps, can also provide evidence of how certain interventions may or may not be received by the present stakeholders. Indeed, their interpretation of external influencing factors (Van Assche et al., 2014) can determine the success (or otherwise) of different types of intervention. On this basis, the same policy intervention in two Statist-macro countries may have two very different outcomes based upon this interpretation. Within this there is the added layer of complexity in relation to the stakeholder networks that exist and the relationships and resource links that occur/flow between them. It is crucial that academics, policy-makers and social enterprise support organisations understand these in order to better understand how different interventions to support an ecosystem will enable or constrain the emergence and growth of social enterprises.

By evidencing the existence of different social enterprise ecosystem types across Europe, this paper contributes an insight into the conditions that exist within individual countries, the forms of social enterprise that therefore emerge, and the forms of support that may or may not lead to positive systemic change in the ecosystem. Further research is required to explore these individual ecosystems types in greater detail and to identify where other European countries outside of the scope of this project belong on the typology map. In addition, as this framework accepts the fluid nature of social enterprise ecosystems, further research that seeks to explore the trajectories of each ecosystem, and the dynamic processes within them, would also be beneficial to increasing our understanding of social enterprise on an international comparative basis. 


\section{References}

Arthur, L, Keenoy, T., Scott-Cato, M. and Smith, R., (2006), "Where Is the 'Social' in Social Enterprise?" In Interrogating Alterity: Alternative Economic and Political Spaces, edited by Duncan Fuller, Andrew EG Jonas, and Roger Lee, 207-22. Ashgate Economic Geography Series. Aldershot: Ashgate Publishing Ltd.

Baumol, W., (1990), Entrepreneurship: Productive, unproductive, and destructive, Journal of Political Economy, 98(5), pp. 893-921.

Brass, D. J., (1984), Being in the right place: A structural analysis of individual influence in an organization, Administrative Science Quarterly, 29, pp. 518-539.

Defourny, J. \& Nyssens, M., (2008), Social enterprise in Europe: recent trends and developments, Social Enterprise Journal, 4(3), pp. 202-228.

Defourny, J., \& Nyssens, M. (2010), Conceptions of Social Enterprise and Social Entrepreneurship in Europe and the United States: Convergences and Divergences. Journal of Social Entrepreneurship, 1(1), 32-53.

Dey, P. \& Steyaert, C., (2012), Social entrepreneurship: Critique and the radical enactment of the social, Social Enterprise Journal, 8(2), pp. 90-107.

Dey, P. \& Steyaert, C., (2014), Rethinking the space of ethics in social entrepreneurship: Power, subjectivity and practices of freedom, Journal of Business Ethics, 133, pp. 627641.

Dey, P. \& Teasdale, S., (2016), The tactical mimicry of social enterprise strategies: Acting 'as if' in the everyday life of third sector organisations, Organization, 23(4), pp. 485504.

Doherty, B., Foster, G., Mason, C., Meehan, J., Meehan, K., Rotheroe, N. and Royce, M., (2009), Management for Social Enterprise, London, Sage Publications.

During, R., (2014), The Evolutionary Perspective on Social Enterprise, EFESEIIS FP7 Draft Paper - July 2014.

During, R., Van Dam, R. \& Salverda, I., (2016), Using evolutionary theory for pluralism in social policies, Conference paper presented at the Social Policy Association Conference, July $4^{\text {th }}-6^{\text {th }} 2016$ Belfast.

Galera, G., \& Borzaga, C. (2009), Social Enterprise: An International Overview of Its Conceptual Evolution and Legal Implementation. Social Enterprise Journal, 5(3), 210-228.

Glaser, B. G. \& Strauss, A. L. (1967), The Discovery of Grounded Theory, Chicago. IL: Aldine.

Granovetter, M., (1985), Economic action and social structure: The problem of embeddedness. American Journal of Sociology, 91, pp. 481-510. 
Grassl, W., (2012), Business Models of Social Enterprise: A Design Approach to Hybridity, ACRN Journal of Social Entrepreneurship Perspectives, 1(1), pp. 37-60.

Haugh, H. (2007), Community-Led Social Venture Creation, Entrepreneurship, Theory \& Practice, Vol. 31, Issue 2, pp. 161-182.

Hazenberg, R., Bajwa-Patel, M., Roy, M.J., Mazzei, M. and Baglioni, S. (2016), “A Comparative Overview of Social Enterprise 'Ecosystems' in Scotland and England: An Evolutionary Perspective”, International Review of Sociology, Vol. 26 No. 2, pp. 205-222.

Jack, S. L., (2005), The role, use and activation of strong and weak network ties: A qualitative analysis, Journal of Management Studies, 42, pp. 1233-1259.

Jones, R., Betta, M., Latham, J. and Gross, D., (2009), Female social entrepreneurship as a discursive struggle, AGSE, pp. 871-85.

Kerlin, J.A. (2006), "Social Enterprise in the United States and Europe: Understanding and Learning from the Differences." VOLUNTAS: International Journal of Voluntary and Nonprofit Organizations, 17(3), pp. 246-62.

Kerlin, J.A. (2010), “A Comparative Analysis of the Global Emergence of Social Enterprise." VOLUNTAS: International Journal of Voluntary and Nonprofit Organizations, 21, pp. 162-79.

Kerlin, J. A. (2013), Defining Social Enterprise Across Different Contexts: A Conceptual Framework Based on Institutional Factors, Nonprofit and Voluntary Sector Quarterly, 42(1), pp. 84-108.

Lincoln, Y. \& Guba, E. (1985), Naturalistic Inquiry, Beverly Hills, CA: Sage.

Luhmann, N, (1989), Ecological communication, University of Chicago Press, Chicago.

Maturana, H. \& Varela, F., (1987), The tree of knowledge: The biological roots of human understanding, Boston: Shambhala Publications.

Maykut, P. S. \& Morehouse, R. (1994), Beginning qualitative research: A philosophic and practical guide, Falmer Press: London and Washington DC.

McKay, S., Moro, D., Teasdale, S. \& Clifford, D., (2015), The marketisation of charities in England and Wales, Voluntas, 26(1), pp. 336-354.

McLeod, J. (1994), Doing Counselling Research, London: Sage.

Mehra, A., Kilduff, M., \& Brass, D. J., (2001), The social networks of high and low selfmonitors: Implications for workplace performance. Administrative Science Quarterly, 46, pp. 121-146.

Mendell, M., (2010), Reflections on the evolving landscape of social enterprise in North America, Policy and Society, 29(3), pp. 243-256. 
Nicholls, A., (2010), The legitimacy of social entrepreneurship: Reflexive isomorphism in a pre-paradigmatic field, Entrepreneurship, Theory and Practice, 34(4), pp. 611633.

North, D., (1990), Institutions, institutional change, and economic performance, Cambridge: Cambridge University Press.

Puumalainen, K., Sjögrén, H., Syrjä, P. \& Barraket, J., (2015), Comparing social entrepreneurship across nations: An explanatory study of institutional effects, Canadian Journal of Administrative Sciences, 32, pp. 276-287.

Qureshi, I., Kistruck, G.M. \& Bhatt, B., (2016), The enabling and constraining effects of social ties in the process of institutional entrepreneurship, Organization Studies, 37(3), pp. 425-447.

Roy, MJ, McHugh, N., Huckfield, L., Kay, A. and Donaldson, C. (2015) “'The Most Supportive Environment in the World'? Tracing the Development of an Institutional 'Ecosystem' for Social Enterprise.” Voluntas, 26(3), pp. 777-800.

Salamon, L.M., Sokolowski, S.W. \& List, R., (2003), Global civil society: An overview, The John Hopkins Comparative Nonprofit Sector Project, available online at http://ccss.jhu.edu/wpcontent/uploads/downloads/2011/09/Book_GCSOverview_2003.pdf (accessed on Wednesday 5th October 2016).

Smith, B.R. \& Stevens, C.E., (2010), Different types of social entrepreneurship: The role of geography and embeddedness on the measurement and scaling of social value, Entrepreneurship \& Regional Development, 22(6), pp. 575-598.

Teasdale, S. (2012), What's in a Name? Making Sense of Social Enterprise Discourses. Public Policy and Administration, 27(2), pp. 99-119.

Uzzi, B., (1996), The sources and consequences of embeddedness for the economic performance of organizations: The network effect, American Sociological Review, 61, pp. 674-698.

Van Assche, K., Beunen, R. \& Duineveld, M., (2014), Evolutionary Governance Theory: An Introduction, Springer, Wageningen.

Williamson, O., (2000), The new institutional economics: taking stock, looking ahead, Journal of Economic Literature, 38(3), pp. 595-613.

Zafeiropoulou, F.A. \& Koufopoulos, D.N., (2013), The Influence of Relational Embeddedness on the Formation and Performance of Social Franchising, Journal of Marketing Channels, 20(1-2), pp. 73-98. 